\title{
Effect of organic acids or monensin-sodium addition on fatty acid production of short chain and methane through the ruminal fermentation "in vitro"
}

\author{
Efeito da adição de ácidos orgânicos ou monensina sódica na \\ produção de ácidos graxos de cadeia curta e metano através da \\ fermentação ruminal "in vitro"
}

\author{
Alisson Minozzo da Silveira ${ }^{1 *}$; Julio Viégas ${ }^{2}$ : Cimélio Bayer ${ }^{3}$; \\ Gilberto Vilmar Kozloski²; Weiler Giacomazza Cerrutti' ${ }^{1}$; Guidiane Moro ${ }^{1}$; \\ Stela Naetzold Pereira ${ }^{4}$; Tiago João Tonin ${ }^{1}$; Rotchyelly Prestes Carpes ${ }^{4}$; \\ Lisiani Rorato Dotto ${ }^{4}$; Diego Prado de Vargas ${ }^{5}$
}

\begin{abstract}
Food additives may increase food and animal production efficiency, as well as reduce the production of enteric methane $\left(\mathrm{CH}_{4}\right)$. With the aim to evaluate the influence of organic additives in two concentrations $(250$ and $500 \mathrm{ppm})$ in the production of $\mathrm{CH} 4(\mathrm{~mL})$, short chain fatty acids (SCFA), ammonia nitrogen (N-NH3) and $\mathrm{pH}$, an experiment "in vitro" gas was conducted, having two control groups, one as a negative control without the presence of additive and another as a positive control, with the addition of monensin-sodium (30ppm). The experiment was arranged in a completely randomized design with three replications. The treatment with monensin-sodium increased the propionate production $(p<0.05)$ and decreased $(p<0.05) \mathrm{CH}_{4}$, acetate, butyrate, valerate, isobutyrate, isovalerate production, the acetate/ propionate ratio and total SCFA production compared to treatment without additive, the $\mathrm{N}-\mathrm{NH}_{3}$ concentration being unchanged. Among CTX 250 and 500 organic acids treatments, only 500 CTX showed a trend $(p<0.10)$ to decrease in $\mathrm{N}^{-\mathrm{NH}_{3}}$ concentrations, with no significant changes $(p>0.05)$ in the remaining parameters related to treatment without additives. In this sense, monensin-sodium shows characteristics of modulation of rumen environment.
\end{abstract}

Key words: Food additives, ionophores, ammonia nitrogen, $\mathrm{pH}$

\section{Resumo}

Aditivos alimentares podem aumentar a eficiência dos alimentos e a produção animal, bem como reduzir a produção de metano $\left(\mathrm{CH}_{4}\right)$ entérico. Com objetivo de avaliar a influência de aditivos orgânicos

\footnotetext{
${ }^{1}$ Discentes do Curso de Pós-Graduação em Zootecnia, Dept ${ }^{\circ}$ de Zootecnia, Universidade Federal de Santa Maria, UFSM, Santa Maria, RS, Brasil. E-mail: alissonmsilveira@gmail.com; weiler_cerutti@yahoo.com.br; guidiane@gmail.com; tiagojtonin@ gmail.com

2 Profs. Drs., Dept ${ }^{\circ}$ de Zootecnia, UFSM, Santa Maria, RS, Brasil. E-mail: jviegas.ufsm@gmail.com; gilberto.kozloski@ufsm.br

${ }^{3}$ Prof. Dr., Dept ${ }^{\mathrm{o}}$ de Solos, Universidade Federal do Rio Grande do Sul, UFRGS, Porto Alegre, RS, Brasil. E-mail: cimelio.bayer@ ufrgs.br

${ }^{4}$ Discentes do Curso de Graduação em Zootecnia, Dept ${ }^{\circ}$ de Zootecnia, UFSM, Santa Maria, RS, Brasil. E-mail: snaetzold@gmail. com; rotchyelly.carpes@gmail.com; lisianidotto@gmail.com

${ }_{5}^{5}$ Discente do Curso de Doutorado, Dept ${ }^{\circ}$ de Tecnologia e Ciência dos Alimentos, UFSM, Santa Maria, RS. Brasil. E-mail: diegodevargas@hotmail.com

* Author for correspondence
} 
em duas concentrações (250 e 500ppm) na produção de $\mathrm{CH}_{4}(\mathrm{~mL})$, ácidos graxos de cadeia curta (AGCC), nitrogênio amoniacal $\left(\mathrm{N}_{-} \mathrm{NH}_{3}\right)$ e no $\mathrm{pH}$, foi conduzido um experimento "in vitro" gás, tendo dois controles, um negativo sem a presença de aditivo e outro positivo, com à adição de monensina sódica $(30 \mathrm{ppm})$. O experimento foi organizado em um delineamento inteiramente casualizado, com três repetições. $\mathrm{O}$ tratamento com monensina sódica aumentou $(\mathrm{p}<0.05)$ a produção de propionato e diminuiu ( $\mathrm{p}<0.05$ ) a produção de $\mathrm{CH}_{4}$, acetato, butirato, valerato, isobutirato, isovalerato, a relação de acetato/propionato e a produção total AGCC em relação ao tratamento sem aditivo, não alterando a concentração de $\mathrm{N}_{-} \mathrm{NH}_{3}$. Dos tratamentos com ácidos orgânicos CTX 250 e 500, somente o CTX 500 mostrou tendência $(\mathrm{p}<0.10)$ a diminuição nas concentrações de $\mathrm{N}^{-\mathrm{NH}_{3}}$, sem alterações significativas ( $>0.05)$ nos demais parâmetros avaliados em relação ao tratamento sem aditivos. Neste sentido a monensina sódica apresenta características de modulação do ambiente ruminal.

Palavras-chave: Aditivos alimentares, ionóforos, nitrogênio amoniacal, $\mathrm{pH}$

\section{Introduction}

Scientific progress on animals requirements and food nutritive values made technical knowledge and necessary information available to researchers for accurate balancing diets. Therefore, the discovery of substances that control animal metabolism, increasing the efficiency of feed utilization, has led to a new class of substances known as food additives. Additives are substances or mixtures of substances added to feed in order to increase animal production, and also enhancing the products quality of animal origin. Among additives: ionophore and nonionophore antibiotics, yeast, probiotics, prebiotics, essential oils, plant extracts and organic acids are currently used in ruminants' diets (BERCHIELLI et al., 2011).

Ionophores were initially used as coccidiostats in poultry, becoming also used as growth promoters for cattle since 1975. In the rumen they inhibit gram-positive bacteria (acetate producers), but not the growth of gram-negative propionate producers, causing decrease in acetate: propionate ratio, promoting a reduction in methane production, increasing consequently the energy efficiency of ruminants (RUSSELL; STROBEL, 1989).

The monensin is certainly the most studied and used however in recent years, its use has undergone several constraints, mainly from the European Union, which in 2006 banned from its market, any animal product that has been produced with promoting growth antibiotic usage (EUROPEAN
UNION, 2003). This legislation also abolished animal products importation from countries that make use of this ingredient.

The WHO (World Health Organization) also considers antibiotics use in animal production an increasing risk to the human health, due to the microorganism's possible resistance to antibiotics (FAO et al., 2004). Given these constraints, there has been a growing interest in the additives research that offers similar results as ionophores, however with no human health risks. As a result, organic products have been studied in order to manipulate rumen fermentation, increasing animal feed efficiency, thereby reducing the limitations imposed by some consumers markets, regarding milk and beef consumption, produced with growth-promoters of synthetic origin.

With the aim of evaluating the use of a product based on organic acids, resulting from the activation of ascorbic acid with natural organic acids (citric and lactic) in a matrix glycerin against a monensinsodium additive in the production of short chain fatty acids and methane was developed the present work using the production technique of "in vitro" gas.

\section{Material and Methods}

The study was conducted from December 2011 to May 2012, at Food Science and Nutrition of Ruminants Laboratory (LABRUMEN), of Animal 
Science Department, Federal University of Santa Maria, in Santa Maria, RS, Brazil, located in the physiographic region known as Central Depression, with the coordinates $29^{\circ}$ and $43^{\prime}$ South Latitude and $53^{\circ}$ and $42^{\prime}$ 'West Longitude.

Two types of additives were tested, totaling four treatments: CTL (control, no additive), MON (ionophore monensin-sodium), CTX250 (250ppm organic additive) and CTX500 (500ppm organic additive). For MON treatment Rumensin (Elanco $\left.{ }^{\circledR}\right)$ commercial product was used at the dosage recommended by the manufacturer, $2 \mathrm{~g} /$ animal/day. Minimal dosage of monensin-sodium in the product is $100 \mathrm{mg}$ per gram of Rumensin (Elanco $\left.{ }^{\circledR}\right)$. As for CTX treatments a commercial product based on organic acids was used, resulting on the ascorbic acid activation with natural organic acids (citric and lactic) in a glycerin matrix at 250 and 500ppm concentrations. The 250ppm concentration being the one recommended by the manufacturer.

For calculation basis a bovine with an average live weight of $400 \mathrm{~kg}$ was taken as standard and a $60 \mathrm{~L}$ rumen volume ( $15 \%$ of body weight), then $1,67 \mathrm{mg}$ Rumensin ${ }^{\circledR}$ were added to the MON treatment, $1,69 \mathrm{mg}$ and 3,38mg of organic product for CTX250 and 500 treatments respectively, in each bottle containing $50 \mathrm{~mL}$ of the incubation solution.

The gas production in vitro technique (THEODOROU et al., 1994) was adapted to the semi-automatic system (MAURICIO et al., 1999), using a pressure transducer (800 Date Pressure Press, Piracicaba, SP - Brazil), to estimate digestibility, the SCFA production, $\mathrm{N}-\mathrm{NH}_{3}$ and $\mathrm{CH}_{4}$.

As food elements, Cynodon spp hay cv. tifton 85 (bulky) and corn (concentrate) were used, predried under forced air in an oven $\left(55-60^{\circ} \mathrm{C} / 72 \mathrm{~h}\right)$, ground into a $1 \mathrm{~mm}$ Willey sieve. These foods were used as fermentation substrate, obeying the bulky/ concentrate proportion of 55:45 ratio. Treatments with additives were manually added to the food mixture, at concentrations described above. Substrate samples weighing $0.5 \mathrm{~g}$, were placed into fermentation bottles of $100 \mathrm{~mL}$ volume capacity, in which was added $40 \mathrm{~mL}$ of culture medium (buffer), as described by Theodorou et al. (1994). The bottles were sealed with rubber stoppers $(14 \mathrm{~mm})$ and sealed with aluminum bands. To prevent the occurrence of any type of fermentation, bottles were stored in a refrigerator at $4^{\circ} \mathrm{C}$ for the period $(8-12 \mathrm{~h})$ prior to inoculation.

The bottles containing the substrate and culture medium were removed from the refrigerator and placed in a water bath at $39^{\circ} \mathrm{C}$ five hours before the inoculation. The rumen fluid was obtained from fistulated cattle and fed with the same experimental diet based on forage and concentrate; the material was collected and stored, according to the gas production in vitro technique (MAURICIO et al., 1999). The rumen fluid was filtered through two layers of cotton gauze under continuous $\mathrm{CO}_{2}$ injection and kept in a water bath at $39^{\circ} \mathrm{C}$. Volumes of $10 \mathrm{~mL}$ of filtrated rumen fluid were injected into the bottles of the above respective treatments. Flasks containing rumen liquid and culture medium (buffer) were used as white, to discount the gas production coming from the ruminal fluid. After the rumen fluid inoculation, bottles were sealed and placed in a water bath at $39^{\circ} \mathrm{C}$ and constant stirring for 48 hours.

The pressure caused by gases accumulated at the bottles top, was measured via a pressure transducer connected at its end to a needle $(0.6 \mathrm{~mm})$. Pressure readings were taken at times 2 , $4,6,8,10,12,18,24,30,36$ and 48 hours after the incubation. From the needle insertion into the rubber stopper, the pressure produced within the bottles was read on the digital player pressure transducer.

For the pressure readings interpretation (psi = pressure per square inch) was used in the following equation $\mathrm{V}=4,9515 \mathrm{p}+0.656$. Where $\mathrm{V}=$ gas volume $(\mathrm{mL}) ; \mathrm{p}=$ measured pressure ( $\mathrm{psi}$ ), this equation allows the conversion of the gas measurements, made in psi through the pressure transducer, to 
millimeters. The total gas production was taken as the sum of each reading partial production.

Relating to SCFA production analysis, $1 \mathrm{~mL}$ samples of the bottles fermentation liquid were collected with $1 \mathrm{~mL}$ syringe and needle at incubation times 0, 6, 12, 24 and 48 hours, these samples stored in Eppendorf tubes, frozen and sent in isothermal boxes to the LANA-UNESP Laboratory, Jaboticabal, SP, Brazil. In the laboratory, for the SCFA concentrations determination, samples were centrifuged at $30,000 \mathrm{rpm}$ for 30 minutes at $10^{\circ} \mathrm{C}$, after the $0.5 \mathrm{~mL}$ supernatant, $0.1 \mathrm{~mL}$ of formic acid was added for the gas chromatography analysis (SHIMADZU, GC-2014 model), equipped with a flame ionization detector (FID), using a HPINNOwax 19091N-213 capillary column (30m, $0.32 \mathrm{~mm}, 0.5 \mu \mathrm{m})$. The injector temperature was $200^{\circ} \mathrm{C}$ and the detector $250^{\circ} \mathrm{C}$. The injection was in "split" mode, with 1:30 ratio, using nitrogen as a carrier gas. The external calibration curve was made with chromatographic patterns (Chem Service, West Chester, PA, USA) for acetic acid (99.5\%; CAS 64-19-97), propionic acid (99\%; CAS 09-0479), isobutyric acid (99\%; CAS 79-31-2), butyric acid (98.7\%; CAS 107-92-6), isovaleric (99\%; CAS 503-74-2) and valeric acid (99\%; CAS 109-52-4).

For $\mathrm{N}_{-} \mathrm{NH}_{3}$ determination, $100 \mu \mathrm{L}$ of the fermentation liquid sample was collected at the same time of SCFA collections and, diluted and analyzed by the hypochlorite phenol method (WEATHERBURN, 1967). After 48 hours of incubation, the bottles were opened and $\mathrm{pH}$ was measured with a digital potentiometer (Digimed DM21, São Paulo, SP - Brazil).

The $\mathrm{CH}_{4}$ determination was performed in an independent test measurement, with pressure and gas collection higher intervals, following the same methodology above. The scan times were 6, 12, 24 and 48 hours, where the pressure reading was done at each time, with the use of a three-way stopcock system coupled, a $10 \mathrm{~mL}$ sample of produced gas was collected, through a syringe that was stored in glass bottles with rubber cover and double silicone layer, which were sent for analysis in "extainer" type vacuum tubes and sent to the Environmental Biogeochemistry Laboratory, Department of Soils Science at UFRGS, Porto Alegre, RS, Brazil. The $\mathrm{CH}_{4}$ concentration in air samples was analyzed through gas chromatography (GC-2014 mod. "Greenhouse") in a FID detector, operating at $250^{\circ} \mathrm{C}$ from one $\mathrm{mL}$ auto-sampler and using $\mathrm{N}_{2}$ as carrier gas (MOTERLE et al., 2013).

To calculate the methane amount produced, the equation " $\mathrm{CH}_{4}=(\mathrm{GP}+\mathrm{HS}) \times$ Conc" was used; where $\mathrm{CH}_{4}$ is the volume ( $\left.\mathrm{ml}\right)$ of methane, GP the volume $(\mathrm{mL})$ of produced gas at the end of each incubation period, HS the volume $(\mathrm{mL})$ of the bottle "headspace" and Conc is the methane concentration in the gas of sample analyzed (TAVENDALE et al., 2005).

The experimental design for "in vitro" production gases was completely randomized with 4 treatments and 3 replications (bottles) and repeated measures through time. Also for SCFA, $\mathrm{N}-\mathrm{NH}_{3}$ and $\mathrm{CH}_{4}$ quantification, the experimental design was completely randomized with three replications (bottles), in a 4 x 4 factorial design and the following factors: 4 treatments (CTL, MON, CTX250 and CTX 500) and 4 incubation times (6, 12, 24, 48h.).

The SCFA, $\mathrm{N}-\mathrm{NH}_{3}$ and $\mathrm{CH}_{4}$ gas production data were subjected to variance analysis and $\mathrm{F}$ test using the PROC MIXED procedure. When the F test was significant, the treatment averages were compared using the Tukey's test, with significance level at $p \leq 0.05$ and trends at $p>0.06$ and $<0.10$, using the SAS (Statistical Analysis System, version 9.2).

\section{Results and Discussion}

The monensin-sodium decreased $(p<0.05)$ the gas production compared to control, which was not observed in the CTX 250 and 500 organic acids treatments. This decrease is due mainly to 
its action in methanogenic bacteria, providing a lower methane production and consequently lower total gas production, as can be seen in figure 1 . On average, the gas production reduction was $15 \%$ compared to control, while the methane decrease was more significant, around $60 \%$. This gas production reduction was also observed by Araujo et al. (2011), that testing monensin-sodium in gas "in vitro" system technique found an average decrease of $20 \%$, with variations between 15 and $25 \%$. "In vitro" experiments indicate that monensin reduces the methane production, which can reduce emissions by $25 \%$ (VAN NEVEL; DEMAYER, 1995), reaching reductions in $\mathrm{CH}_{4}$ total production of 48,52 and $58 \%$, as were observed when using in "in vitro" gas technique with $2.5 ; 5.0$ and $12.5 \mathrm{mg} / \mathrm{L}$ of monensin, respectively (RUSSELL; STROBEL, 1989).

Figure 1. Gas production accumulated values $(\mathrm{mL})$ and methane $(\mathrm{mL})$ observed for different treatments: control, without the use of additives (CTL), monensin-sodium (MON) and organic additive 250 and 500 ppm (CTX 250 e CTX500) respectively, within 48 hours of "in vitro" fermentation gas. TREAT= effect of treatment; TIME= effect of incubation time; TREAT*TIME= interaction between treatment and incubation time.

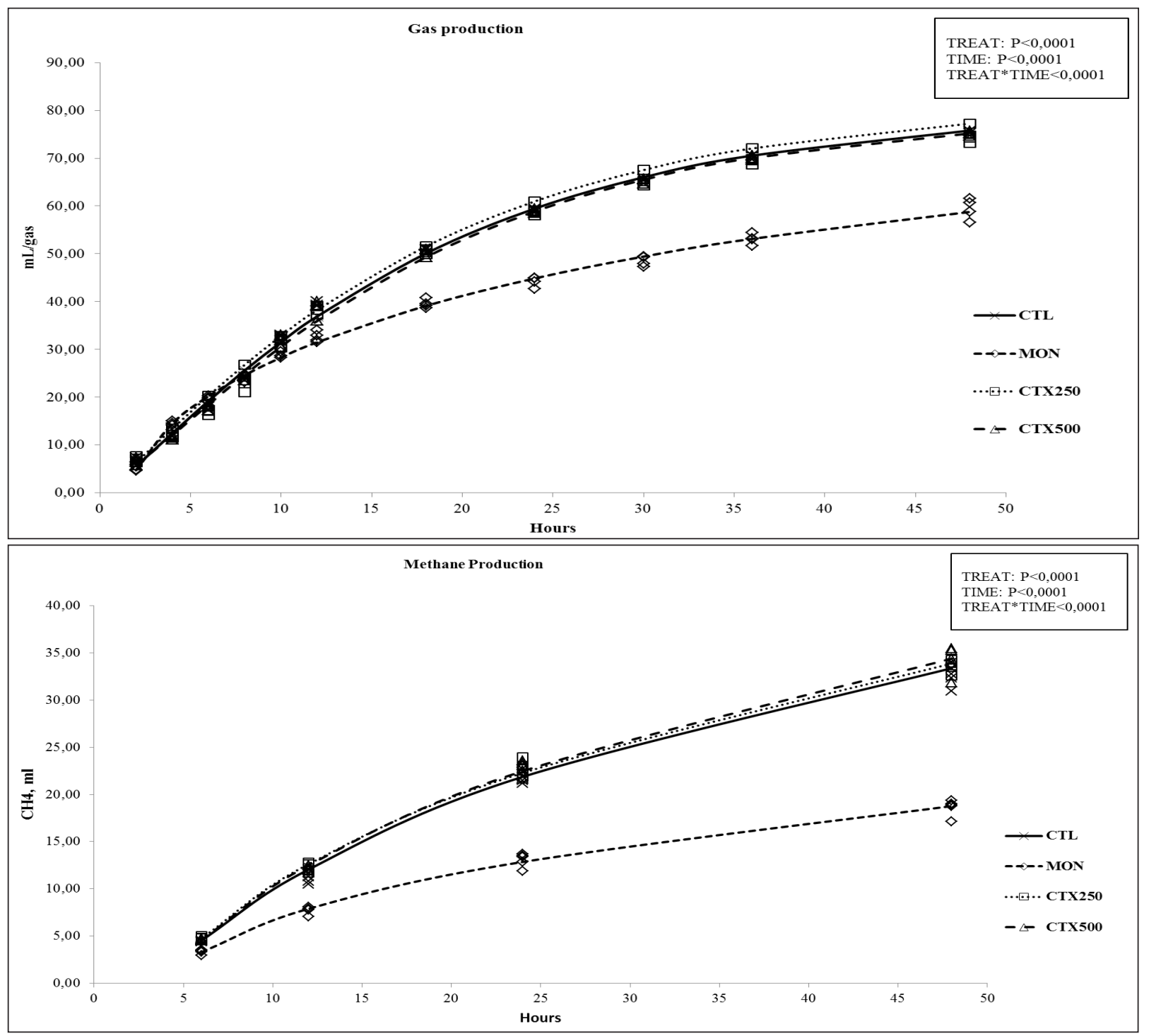


Most studies done with organic acids, such as nutritional additives, concentrate in the malic acid and/or fumaric acid use, intermediates of the citric acid cycle (KHAMPA; WANAPAT, 2007) than when used "in vitro", the same effect of monensin on the gas and methane production reduction are observed (CARRO; RANILLA, 2003; MOHAMMED et al., 2004). Other studies (CALLAWAY; MARTIN, 1996; GOMEZ et al, 2005), found similar results, where there was no gas and methane production reduction through the use of organic acids "in vitro".

There are two hypotheses for the gas and $\mathrm{CH}_{4}$ production decline, caused by monensin-sodium. Firstly, monensin reduces the "in vitro" organic matter degradation, actually sustained by a lower $(p<0.05)$ degradation rate as observed in table
1, for monensin treatment compared to control. This organic matter degradation reduction is a typical limitation of "in vitro" experiments of short duration, for monensin inhibits Gram-positive bacteria related to fermentation, which includes some Ruminococcus sp. cellulolytic. Under "in vivo" conditions, no deleterious effects on fiber degradation are observed, once cellulolytic bacteria tolerant to monensin, under these conditions, are able to replace the sensitive ones (RUSSELL; STROBEL, 1989). The second explanation for the decreased gas and $\mathrm{CH}_{4}$ production is that monensin increases the propionate production (RUSSELL; STROBEL, 1989). According to the stoichiometry of the gas production, the propionate formation is associated to decreases of $\mathrm{CO}_{2}$ and $\mathrm{CH}_{4}$ production (WOLIN, 1960).

Table 1. Parameter estimations of gas production, degradation rate, methane $\left(\mathrm{CH}_{4}\right)$ production, short chain fatty acids production (SCFA), ammonia nitrogen $\left(\mathrm{N}_{-} \mathrm{NH}_{3}\right)$ and $\mathrm{pH}$ observed by "in vitro" gas fermentation under the effect of Monensin-sodium addition (Rumensin $($ ) and additive based on organic acids.

\begin{tabular}{|c|c|c|c|c|c|c|}
\hline \multirow{2}{*}{ Item $^{1}$} & \multicolumn{4}{|c|}{ Treatments $^{2}$} & \multirow{2}{*}{$\begin{array}{c}\text { Significance } \\
\text { of } P\end{array}$} & \multirow{2}{*}{$\mathrm{CV}(\%)$} \\
\hline & CTL & MON & CTX250 & CTX500 & & \\
\hline Gas, mL (48h) & $75,20^{\mathrm{a}}$ & $59,60^{\mathrm{b}}$ & $76,25^{\mathrm{a}}$ & $74,06^{\mathrm{a}}$ & 0,0001 & 2,04 \\
\hline Degradation Tax. \%/h & $3,47^{\mathrm{a}}$ & $2,26^{\mathrm{b}}$ & $3,50^{\mathrm{a}}$ & $3,52^{\mathrm{a}}$ & 0,0001 & 4,00 \\
\hline $\mathrm{CH}_{4}, \mathrm{~mL}(48 \mathrm{~h})$ & $32,61^{\mathrm{a}}$ & $18,61^{b}$ & $33,52^{\mathrm{a}}$ & $34,15^{\mathrm{a}}$ & 0,0001 & 3,59 \\
\hline \multicolumn{7}{|l|}{ SCFA, mM (48h) } \\
\hline Total & $93,77^{\mathrm{a}}$ & $81,87^{\mathrm{b}}$ & $92,26^{\mathrm{a}}$ & $93,82^{\mathrm{a}}$ & 0,0001 & 1,78 \\
\hline $\begin{array}{c}\text { Acetate } \\
(\%)\end{array}$ & $\begin{array}{l}60,66^{a} \\
(64,69)\end{array}$ & $\begin{array}{l}47,93^{b} \\
(58,54)\end{array}$ & $\begin{array}{c}59,89^{\mathrm{a}} \\
(64,91)\end{array}$ & $\begin{array}{c}60,95^{\mathrm{a}} \\
(64,96)\end{array}$ & 0,0001 & 1,60 \\
\hline $\begin{array}{l}\text { Propionate } \\
\text { (\%) }\end{array}$ & $\begin{array}{l}18,45^{\mathrm{b}} \\
(19,67)\end{array}$ & $\begin{array}{l}24,04^{\mathrm{a}} \\
(29,36)\end{array}$ & $\begin{array}{c}18,17^{b} \\
(19,69)\end{array}$ & $\begin{array}{c}18,43^{b} \\
(19,64)\end{array}$ & 0,0001 & 2,98 \\
\hline $\begin{array}{l}\text { Isobutirate } \\
(\%)\end{array}$ & $\begin{array}{l}1,13^{\mathrm{a}} \\
(1,20)\end{array}$ & $\begin{array}{c}0,79^{\mathrm{b}} \\
(0,96)\end{array}$ & $\begin{array}{l}1,13^{\mathrm{a}} \\
(1,22)\end{array}$ & $\begin{array}{l}1,12^{\mathrm{a}} \\
(1,19)\end{array}$ & 0,0001 & 4,27 \\
\hline $\begin{array}{c}\text { Butirate } \\
(\%)\end{array}$ & $\begin{array}{l}10,57^{a} \\
(11,27)\end{array}$ & $\begin{array}{c}6,88^{\mathrm{b}} \\
(8,40)\end{array}$ & $\begin{array}{l}10,10^{\mathrm{a}} \\
(10,94)\end{array}$ & $\begin{array}{l}10,36^{\mathrm{a}} \\
(11,04)\end{array}$ & 0,0001 & 3,86 \\
\hline $\begin{array}{l}\text { Isovalerate } \\
(\%)\end{array}$ & $\begin{array}{c}1,86^{\mathrm{a}} \\
(1,98)\end{array}$ & $\begin{array}{l}1,33^{b} \\
(1,62)\end{array}$ & $\begin{array}{l}1,87^{\mathrm{a}} \\
(2,02)\end{array}$ & $\begin{array}{c}1,84^{\mathrm{a}} \\
(1,96)\end{array}$ & 0,0001 & 4,49 \\
\hline $\begin{array}{c}\text { Valerate } \\
(\%)\end{array}$ & $\begin{array}{l}1,08^{\mathrm{a}} \\
(1,15)\end{array}$ & $\begin{array}{c}0,88^{\mathrm{b}} \\
(1,07)\end{array}$ & $\begin{array}{l}1,08^{\mathrm{a}} \\
(1,17)\end{array}$ & $\begin{array}{l}1,09^{\mathrm{a}} \\
(1,16)\end{array}$ & 0,0017 & 4,66 \\
\hline $\mathrm{C}_{2}: \mathrm{C}_{3}$ & $3,28^{a}$ & $1,99^{\mathrm{b}}$ & $3,29^{a}$ & $3,30^{\mathrm{a}}$ & 0,0001 & 2,01 \\
\hline $\mathrm{N}-\mathrm{NH}_{3}, \mathrm{mg} \mathrm{dL}^{-1}(48 \mathrm{~h})$ & $28,34^{\mathrm{a}}$ & $27,79^{\mathrm{ab}}$ & $26,66^{\mathrm{ab}}$ & $25,99^{\mathrm{b}}$ & 0,0619 & 3,52 \\
\hline $\mathrm{pH}$ & 6,22 & 6,26 & 6,20 & 6,21 & 0,4494 & 0,66 \\
\hline
\end{tabular}

$1 \mathrm{SCFA}=$ Short chain fatty acids; $\mathrm{C} 2: \mathrm{C} 3=$ acetate/propionate ratio.

$2 \mathrm{CTL}=\mathrm{Control} ; \mathrm{MON}=$ Monensin at $30 \mathrm{ppm} ; \mathrm{CTX}=$ Organic additive to at 250 and $500 \mathrm{ppm}$.

Different letters in the same row indicate a significant difference $(\mathrm{P} \leq 0.05)$ according to the Tukey test. 
The concentrations of total SCFA and each SCFA (acetate, propionate, butyrate, valerate, isobutyrate and isovalerate) were similar $(p<0.05)$ among organic acids treatments and control, within 48 hours of gas "in vitro" incubation. Carro and Ranilla (2003), observed an increase in SCFA total concentration, and also a propionate and butyrate production increase, with no change in the acetate production, when the malic acid is added to the "in vitro" culture system. However, Callaway and Martin (1996), using different levels of malic and fumaric organic acids, observed no changes in SCFA total concentration, and similar results were observed in treatments with the organic acids mixture in the present work.

While in the monensin-sodium treatment there was a change in SCFA molar ratio (Figure 2). In SCFA total production there was a decrease of around $12 \%$ compared to control. These results differ from those reported by Castillejos et al. (2008) and Makkar (2004), who observed the same SCFA total production compared to control. The acetate concentration in the monensin-sodium group was approximately $21 \%$ lower compared to control (Table 1). This occurs because grampositive bacteria are sensitive to monensin, for they are large acetate producers (RUSSELL, 2002). Due to the acetate lower production, there is consequently a reduction in $\mathrm{CO}_{2}$ and $\mathrm{H}_{2}$ production, a fact which partially explains the lower $\mathrm{CH}_{4}$ production due to the monensin use (CALLAWAY et al., 2003).

The propionate concentration increased $(p<0.05)$ due to monensin inclusion of approximately $21 \%$ over the control. It is known that stimulating of propionate production causes reduction in the $\mathrm{CH}_{4}$ production. The propionate producing metabolic pathways compete with methanogenesis for $\mathrm{H}_{2}$ (RUSSELL, 2002). Several microorganisms that produce propionate (Ex: Selenomonas ruminantium and Megasphaera elsdenii) are not affected by monensin supply (CALLAWAY et al., 2003). The butyrate and valerate concentrations were lower $(p<0.05)$ when monensin was used as additive. The butyrate production is usually reduced by monensin, once ionophores inhibit Butyrivibrio fibrisolvens gram-positive bacterium, which is considered the largest butyrate producer (RUSSELL, 2002).

As for iso-acids, monensin reduced $(p<0.05)$ isobutyrate and isovalerate concentration around $30 \%$ (Table 1). The iso-acids concentrations reductions indicate a lower deamination, as they are originated from the catabolism of amino acids of branched chain, such as valine and leucine. The lowest dietary deamination in rumen is compensated by its increased use in the small intestine (RUSSELL, 2002). This leads to a lower conversion of proteins and amino acids into ammonia, resulting in a decrease of ammonia loss in urine by urea, providing a nitrogen better use of diet. Busquet et al. (2006) also observed a lower "in vitro" isoacids concentration with $12.5 \mathrm{mg} / \mathrm{L}$ of monensin. The C2:C3 ratio decreased by monensin addition $(p<0.05)$, but did not changed by the organic acids treatment, once acetate and propionate production values were similar to control. Despite a lower $\mathrm{C} 2$ :C3 ratio provided by monensin, we have to point out that SCFA total production was reduced with its use. 
Figure 2. The concentration of short chain fatty acids; acetate, propionate, butyrate and valerate observed for different treatments: control, without the use of additives (CTL), monensin-sodium (MON) and organic additive 250 and 500ppm (CTX250 e CTX500) respectively, within 48 hours of fermentation "in vitro" gas accumulated data over time. TREAT= effect of treatment; TIME= effect of incubation time; TREAT*TIME $=$ interaction between treatment and incubation time

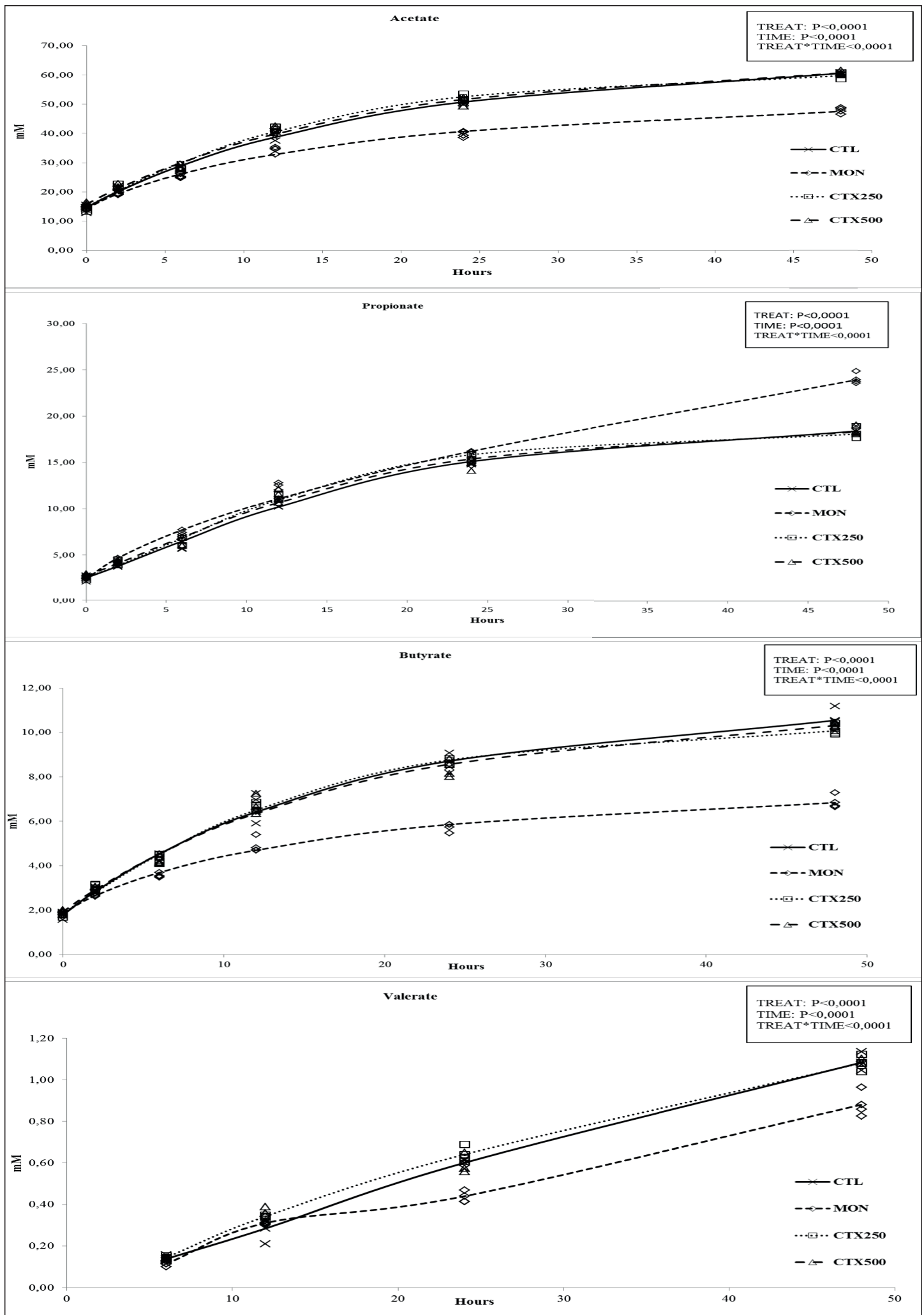


When analyzing the ammonia nitrogen production, we realize that there was a decrease tendency $(p<0.10)$ of $\mathrm{N}_{-} \mathrm{NH}_{3}$ concentration to treatment with organic acids in 500ppm concentration over control, while the monensinsodium treatment and 250ppm organic acids did not differ $(p>0.05)$ compared to control at 48 hours of incubation. This possibly indicates that organic acids of the present work control the proteolytic and deamination bacteria, providing reduced production of ammonia nitrogen. However, no change in the iso-acids production, which are products of amino acids and proteins degradation, was observed. Therefore, we should treat with caution the $\mathrm{N}-\mathrm{NH}_{3}$ reduction, requiring further studies to confirm this inhibitory action of proteolysis and deamination afforded by organic acids.

There were no significant differences $(p>0.05)$ in $\mathrm{pH}$ values among the different "in vitro" treatments. The monensin-sodium "in vivo" may cause $\mathrm{pH}$ elevation, mainly by inhibiting lactateproducing bacteria, ex: Streptococcus bovis (RUSSELL; STROBEL, 1989). While organic acids (malate, fumarate and aspartate) in rich lactate medium, stimulate the Selenomonas ruminantium bacteria development. This bacterium has advantages over other microorganisms, surviving to rumen, by being able to ferment different soluble carbohydrates and using lactate, therefore delaying $\mathrm{pH}$ decrease and metabolic problems appearance in the animal (CALLAWAY; MARTIN, 1996). However, the effects inexistence on $\mathrm{pH}$ "in vitro" is quite common, once it is controlled by the buffering agents of the technique culture medium. If they exist, the effect is commonly related to the fermentation inhibition and SCFA lower production (BUSQUET et al., 2006).

\section{Conclusions}

The analyzed organic acids did not achieve results similar to monensin-sodium, not changing the "in vitro" gas there is no change in gas production, methane and the concentration of fatty acids total short chain, as well as the molar ratios of acetate, propionate, butyrate, valerate, isobutyrate, isovalerate and $\mathrm{pH}$. Organic acids tends to decrease the ammonia nitrogen concentration.

\section{References}

ARAUJO, R. C.; PIRES, A. V.; MOURÃO, G. B.; ABDALLA, A. L.; SALLAM, S. M. A. Use of blanks to determine in vitro net gas and methane production when using rumen fermentation modifiers. Animal Feed Science and Technology, Amsterdam, v. 166, n. 6, p. 155162, 2011.

BERCHIELLI, T. T.; PIRES, A. V.; OLIVEIRA, S. G. Nutrição de ruminantes. 2. ed. Jaboticabal: Ed. FUNEP, $2011.616 \mathrm{p}$.

BUSQUET, M.; CALSAMIGLIA, S.; FERRET, A.; KAMEL, C. Plant extracts affect in vitro rumen microbial fermentation. Journal of Dairy Science, Champaign, v. 89, n. 2, p. 761-771, 2006.

CALLAWAY, T. R.; MARTIN, S. A. Effects of organic acid and monensin treatment on in vitro mixed ruminal microorganism fermentation of cracked corn. Journal of Animal Science, Champaign, v. 74, n. 6, p. 1982-1989, 1996.

CALLAWAY, T. R.; EDRINGTON, T. S.; RYCHLIK, J. L.; GENOVESE, K. J.; POOLE, T. L.; JUNG, Y. S.; BISCHOFF, K. M.; ANDERSON, R. C.; NISBET, D. $\mathrm{J}$. Ionophores: their use as ruminant growth promotants and impact on food safety. Current Issues in Intestinal Microbiology, Wymondham, v. 4, n. 1, p. 43-51, 2003.

CARRO, M. D.; RANILLA, M. J. Effect of the addition of malate on in vitro rumen fermentation of cereal grains. British Journal of Nutrition, London, v. 89, n. 2, p. 279288, 2003.

CASTILLEJOS, L.; CALSAMIGLIA, S.; MARTÍNTERESO, J.; TER WIJLEN, H. In vitro evaluation of effects of ten essential oils at three doses on ruminal fermentation of high concentrate feedlot-type diets. Animal Feed Science and Technology, Amsterdam, v. 145, n. 1, p. 259-270, 2008.

EUROPEAN UNION. Regulation EC N ${ }^{\circ} 1831 / 2003$ of the European Parliament and Council of 22 September 2003 on additives for use in animal nutrition. Official Journal of the European Union, v. 268, p. 29-43, 2003. 
FOOD AND AGRICULTURE ORGANIZATION FAO; WORLD ANIMAL HEALTH ORGANIZATION - OIE; WORLD HEALTH ORGANIZATION - WHO. Second Joint FAO/OIE/WHO Workshop on Non-human Antimicrobial Usage and Antimicrobial Resistance, Oslo, 2004. p. 32-141.

GOMEZ, J. A.; TEJIDO, M. L.; CARRO M. D. Influence of disodium malate on microbial growth and fermentation in rumen-simulation technique fermenters receiving medium- and high-concentrate diets. British Journal of Nutrition, London, v. 93, n. 3, p. 479-484, 2005.

KHAMPA, S.; WANAPAT, M. Manipulation of rumen fermentation with organic acids supplementation in ruminants raised in the tropics. Pakistan Journal of Nutrition, Faisalabad, v. 6, n. 1, p. 20-27, 2007.

MAKKAR, H. P. S. Recent advances in vitro gas method for evaluation of nutritional quality of feed resources. In: FAO. FAO animal production and health 160: assessing quality and safety of animal feeds. Rome: FAO, 2004. p. 55-88.

MAURICIO, R. M.; MOULD, F. L.; DHANOA, M. S.; OWEN, E.; CHANNA, K. S.; THEODOROU, M. K. A semi-automated in vitro gas production technique for ruminant feedstuff evaluation. Animal Feed Science and Technology, Amsterdam, v. 79, n. 4, p. 321-330, 1999.

MOHAMMED, N.; LILA, Z. A.; AJISAKA, N.; HAR, K.; MIKUNI, K.; HARA, K.; KANDA, S.; ITABASHI, $\mathrm{H}$. Inhibition of ruminal microbial methane production bycyclodextrin iodopropane, malate and their combination in vitro. Journal of Animal Physiology and Animal Nutrition, Berlin, v. 88, n. 1, p. 188-195, 2004.
MOTERLE, D. F.; SILVA, L. S.; MORO, V. J.; BAYER, C.; ZSCHORNACK, T.; AVILA, L. A.; BUNDT, C. A. Methane efflux in rice paddy field under different irrigation managements. Revista Brasileira de Ciência do Solo, Viçosa, MG, v. 37, n. 2, p. 431-437, 2013.

RUSSELL, J. B. Rumen microbiology and its role in ruminant nutrition. Ithaca: New York, 2002. 119 p.

RUSSELL, J. B.; STROBEL, H. J. Mini review. Effect of ionóforos on ruminal fermentation. Applied and Environmental Microbiology, Washington, v. 55, n. 5, p. 1-6, 1989.

TAVENDALE, M. H.; MEAHGER, L. P.; PACHECO, D.; WALKER, N.; ATTWOOD, G. G.; SIVAKUMARAN, $\mathrm{S}$. Methane production from in vitro rumen incubations with Lotus pedunculatus and Medicago sativa, and effects of extractable condensed tannin fractions on methanogenesis. Animal Feed Science Technology, Amsterdam, v. 123, n. 1, p. 403-419, 2005.

THEODOROU, M. K.; WILLIAMS, B. A.; DHANOA, M. S.; McALLAN, A. B.; FRANCE, J. A simple gas production method using a pressure transducer to determine the fermentation kinetic of ruminant feeds. Animal Feed Science and Technology, Amsterdam, v. 48, n. 2, p. 185-197, 1994.

VAN NEVEL, C.; DEMEYER, D. I. Lipolysis and biohydrogenation of soybean in the rumen in vitro: inhibition by antimicrobials. Journal of Dairy Science, Champaign, v. 78, n. 2, p. 2797-2806, 1995.

WEATHERBURN, M. W. Phenol-hypochlorite reaction for determination of ammonia. Analytical Chemistry, Washington, v. 39, n. 8, p. 971-974, 1967.

WOLIN, M. J. A theoretical rumen fermentation balance. Journal of Dairy Science, Champaign, v. 43, n. 10, p. 1452-1459, 1960. 